\title{
Reliability of movement control tests on the cervical spine
}

\author{
Maja Patroncini ${ }^{1}$, Susanne Hannig ${ }^{2}$, André Meichtry ${ }^{3}$ and Hannu Luomajoki ${ }^{3^{*}}$
}

\begin{abstract}
Background: Movement control impairment reduces active control of movement. Patients with this might form an important subgroup among patients with mechanical cervical pain. Diagnosis is based on the observation of active movement tests. Although widely used clinically, few studies have been performed to determine the reliability of a test battery. The aim of this study was to determine the inter-tester reliability of movement control impairment $[\mathrm{MCl}]$ tests on the cervical spine.

Methods: Forty-five subjects (31 patients with neck pain, 14 healthy controls) were videotaped while performing a standardized test battery consisting of 13 tests of active movement control. Using observation, two experienced physiotherapists independently rated test performances as correct or incorrect. One of them was blinded to all other patient information and both to each other. Kappa coefficients and 95\% confidence intervals [Cl] for inter-tester results were calculated.
\end{abstract}

Results: The kappa values for inter-tester reliability ranged in from 0.47-1.0 of the 13 tests, 2 demonstrated perfect reliability $(k=1.0), 4$ excellent ( $\mathrm{k} 0.81-0.99), 6$ substantial ( $0.61-0.8)$ and 1 good ( $\mathrm{k}$ 0.41-0.6).

Conclusions: The physiotherapists were able reliably rate the majority the tests in this series of motor control tasks. There have been studies performed describing the assessment and treatment of movement control impairment problems and low back pain. However, no study has involved the assessment of the cervical dysfunction subgroup. This study presents a reliable test battery, for clinical use, to perform more specific examination of this subgroup.

Keywords: Movement control impairment, Neck pain, Reliability, Cervical spine

\section{Background}

Neck pain is a common and growing health problem, with a twelve-month prevalence of between $12.1 \%$ and $71.5 \%$ [1-3]. The discussion on the causes of neck pain is controversial. The causes of idiopathic long-term neck pain and traumatic neck pain, especially, are assumed as being multifactorial [1].

Movement control appears to be an important subject in the assessment and treatment of patients with neck pain. Deficient movement control, known as movement control impairment [MCI], is defined as impaired active movement control during functional activities [4]. With regard to the cervical spine, the patient is unable to control the cervical spine during active movement. Different synonyms exist for movement control impairment:

\footnotetext{
* Correspondence: luom@zhaw.ch

${ }^{3}$ Zurich University of Applied Sciences, School of health professions, Institute of Physiotherapy, Technikumstrasse 70, 8400 Winterthur, Switzerland Full list of author information is available at the end of the article
}

movement control dysfunction, movement system impairment or motor control impairment. Clinical instability and segmental instability can also be used as synonyms [5]. Because of deficient control of active movements lesions of the affected structures and pain can occur. MCI, in contrast to movement impairment [MI], is not marked by pain provoking restricted movement. Patients with MI typically suffer from painful restricted movement. Patients with MCI describe their problems in specific postural static positions or during ongoing unidirectional activities. In many cases, the problem is postural or ergonomic.

The subject of movement control has a long history of discussion in research literature. More recent research shows a correlation between movement control deficiency and previous or actually pain [6-10].

Several studies have assessed tests of movement control impairment of the lumbar spine [11-15]. Luomajoki and colleagues [12-14] showed good reliability and validity of 
Table 1 Characterization of tests

\begin{tabular}{|c|c|c|c|c|c|}
\hline & Characterization of tests & Correct & Not correct & Performance & Camera position \\
\hline \multirow[t]{3}{*}{ Rotation } & \multirow{3}{*}{$\begin{array}{l}\text { "Move your head to the right } \\
\text { and back to middle position, } \\
\text { to the left and back to the } \\
\text { middle. Then move your head } \\
\text { once through the whole range } \\
\text { without stopping in the middle } \\
\text { position". }\end{array}$} & Nose stays horizontal & \multirow{2}{*}{$\begin{array}{l}\text { Evasive head movement in } \\
\text { protraction, extension/lateral } \\
\text { flexion or flexion }\end{array}$} & \multirow[t]{3}{*}{ Sitting } & \multirow[t]{3}{*}{ Frontal } \\
\hline & & No lateral flexion & & & \\
\hline & & Continuous movements & $\begin{array}{l}\text { Non-rhythmic movement: } \\
\text { staccato }\end{array}$ & & \\
\hline \multirow[t]{5}{*}{ Lateral flexion } & \multirow{5}{*}{$\begin{array}{l}\text { "Decline your head to the right } \\
\text { and back to the middle, then } \\
\text { to the left and back to the } \\
\text { middle. Then move once from } \\
\text { left to the right without stopping } \\
\text { in the middle". }\end{array}$} & Nose stays in the middle & Rotation & \multirow[t]{5}{*}{ Sitting } & \multirow[t]{5}{*}{ Frontal } \\
\hline & & No rotation & Shoulder elevation & & \\
\hline & & No shoulder elevation & Non-rhythmic movement: & & \\
\hline & & Continuous movements & staccato & & \\
\hline & & & Chin heading & & \\
\hline \multirow[t]{4}{*}{ Extension CTJ } & \multirow{4}{*}{$\begin{array}{l}\text { "Draw in your chin like a little } \\
\text { nod movement and then try } \\
\text { to look to the ceiling". }\end{array}$} & No chin heading & Head protraction & \multirow[t]{4}{*}{ Sitting } & \multirow[t]{4}{*}{ Lateral $90^{\circ}$} \\
\hline & & Slight global extension & Chin heading & & \\
\hline & & in CTJ & Shoulder elevation/ & & \\
\hline & & $\begin{array}{l}\text { No massive distinctive } \\
\text { extension in one segment }\end{array}$ & protraction & & \\
\hline \multirow{4}{*}{$\begin{array}{l}\text { Nod movement } \\
\text { on the wall }\end{array}$} & \multirow{4}{*}{$\begin{array}{l}\text { "Lean against the wall and do } \\
\text { a small nod movement (say yes) } \\
\text { but leave the head on the wall". }\end{array}$} & \multirow{4}{*}{$\begin{array}{l}\text { Head moves up on the } \\
\text { wall } \\
\text { Draw in chin } \\
\text { Flattening of the lordosis }\end{array}$} & Head protraction & \multirow[t]{4}{*}{ Standing } & \multirow[t]{4}{*}{ Lateral $90^{\circ}$} \\
\hline & & & Head moves away from the wall & & \\
\hline & & & Shoulder elevation/protraction & & \\
\hline & & & Inability to draw in chin & & \\
\hline \multirow[t]{2}{*}{$\begin{array}{l}\text { Upper cervical } \\
\text { spine }\end{array}$} & \multirow[t]{2}{*}{$\begin{array}{l}\text { "Tilt your head to the side and } \\
\text { rotate it then to the ceiling." }\end{array}$} & $\begin{array}{l}\text { Visible lateral flexion and } \\
\text { rotation }\end{array}$ & $\begin{array}{l}\text { Head protraction } \\
\text { Shoulder elevation }\end{array}$ & \multirow[t]{2}{*}{ Sitting } & \multirow[t]{2}{*}{ Frontal } \\
\hline & & $\begin{array}{l}\text { No abolishment of lateral } \\
\text { flexion }\end{array}$ & $\begin{array}{l}\text { Further going movement in the } \\
\text { cervical spine }\end{array}$ & & \\
\hline \multirow[t]{3}{*}{$\begin{array}{l}\text { Flexion/Extension } \\
\text { full range }\end{array}$} & \multirow{3}{*}{$\begin{array}{l}\text { "Bring your chin to the } \\
\text { breastbone and move your } \\
\text { head in extension (whole } \\
\text { movement)". }\end{array}$} & $\begin{array}{l}\text { Visible expansion of } \\
\text { mid cervical spine } \\
\text { while flexion }\end{array}$ & $\begin{array}{l}\text { Ventral head translation while } \\
\text { flexion }\end{array}$ & \multirow[t]{3}{*}{ Sitting } & \multirow[t]{3}{*}{ Lateral $90^{\circ}$} \\
\hline & & Rotation axis in the ear & $\begin{array}{l}\text { Deficient upper cervical spine } \\
\text { flexion }\end{array}$ & & \\
\hline & & $\begin{array}{l}\text { Round movements } \\
\text { without protraction }\end{array}$ & & & \\
\hline \multirow[t]{3}{*}{$\begin{array}{l}\text { Upper body } \\
\text { forward - backward }\end{array}$} & \multirow{3}{*}{$\begin{array}{l}\text { "Lean forward with straight } \\
\text { upper body. Lean your upper } \\
\text { body back, stay sitting straight } \\
\text { and come back". }\end{array}$} & & $\begin{array}{l}\text { Cervical or thoracic spine flexion } \\
\text { or extension }\end{array}$ & \multirow[t]{3}{*}{ Sitting } & Lateral $90^{\circ}$ \\
\hline & & in the thoracic spine & Shoulder elevation/protraction & & \\
\hline & & $\begin{array}{l}\text { No movement in the } \\
\text { cervical spine }\end{array}$ & & & \\
\hline Bilateral shoulder & "Lift both shoulders to the & Minimal chin heading & Cervical spine protraction & Sitting & Lateral $90^{\circ}$ \\
\hline & & $\begin{array}{l}\text { Symmetric shoulder } \\
\text { elevation }\end{array}$ & Any kind of evasive movements & & \\
\hline $\begin{array}{l}\text { Unilateral arm } \\
\text { flexion right }\end{array}$ & "Lift your straight arm up". & & $\begin{array}{l}\text { Cervical or thoracic spine flexion } \\
\text { or extension }\end{array}$ & Sitting & $\begin{array}{l}\text { Lateral } 90^{\circ} \\
\text { from the }\end{array}$ \\
\hline and left & & $\begin{array}{l}\text { No evasive movement } \\
\text { in the thoracic spine }\end{array}$ & Shoulder elevation/protraction & & opposite side \\
\hline & & $\begin{array}{l}\text { No movement in the } \\
\text { cervical spine }\end{array}$ & $\begin{array}{l}\text { Evasive movement in head } \\
\text { rotation }\end{array}$ & & \\
\hline Arm flexion $90^{\circ}$ & "Lift up the weight with & Shoulders stays down & Head protraction & Sitting & Lateral $90^{\circ}$ \\
\hline & $\begin{array}{l}\text { stralght arms to } 90 \text { breast } \\
\text { height and bring the weight }\end{array}$ & Head stays still & Chin heading & & \\
\hline & with straight arms back". & Straight line of vision & Extension of cervical spine & & \\
\hline & & & Shoulder elevation & & \\
\hline
\end{tabular}


Table 1 Characterization of tests (Continued)

\begin{tabular}{|c|c|c|c|c|c|}
\hline \multirow{3}{*}{$\begin{array}{l}\text { Forward bending } \\
\text { in Standing }\end{array}$} & \multirow{3}{*}{$\begin{array}{l}\text { "Bend forward and straighten } \\
\text { up again". }\end{array}$} & Slight extension & Head protraction & \multirow[t]{3}{*}{ Standing } & \multirow[t]{3}{*}{ Lateral $90^{\circ}$} \\
\hline & & $\begin{array}{l}\text { Minimal shoulder } \\
\text { protraction }\end{array}$ & Extension of cervical spine & & \\
\hline & & $\begin{array}{l}\text { Look towards the } \\
\text { ground }\end{array}$ & & & \\
\hline \multirow{4}{*}{$\begin{array}{l}\text { Neck flexion in } \\
\text { supine position }\end{array}$} & \multirow{4}{*}{$\begin{array}{l}\text { "Draw in your chin and lift } \\
\text { your head off the floor". }\end{array}$} & Round movements & Head protraction & \multirow[t]{4}{*}{ Supine } & \multirow[t]{4}{*}{ Lateral $90^{\circ}$} \\
\hline & & \multirow{3}{*}{$\begin{array}{l}\text { No loss of upper } \\
\text { cervical flexion }\end{array}$} & Tremor & & \\
\hline & & & Inability to lift the head & & \\
\hline & & & Inability to draw in chin & & \\
\hline \multirow[t]{2}{*}{ Pro/retraction } & \multirow{2}{*}{$\begin{array}{l}\text { "Move your chin forward } \\
\text { and backward". }\end{array}$} & Horizontal nose-ear line & Shoulder elevation/protraction & \multirow[t]{2}{*}{ Sitting } & \multirow[t]{2}{*}{ Lateral $90^{\circ}$} \\
\hline & & $\begin{array}{l}\text { No cervical spine } \\
\text { extension while } \\
\text { retraction }\end{array}$ & $\begin{array}{l}\text { Forward-backward movement } \\
\text { of upper body }\end{array}$ & & \\
\hline
\end{tabular}

CTJ:Cervicalthoracic Junction.

movement control tests on the lumbar spine. However, compared to the lumbar spine, studies on the cervical spine are still sparse.

There is no gold standard for MCI assessment of the cervical spine [16]. According to O'Leary and collegues [17], the diagnosis of movement control should be based on the visual observation of active movements and functional activities in different starting positions. Little literature exists on the assessment of MCI of the cervical spine. To date, only basic measures for quantifying head and neck movements have been investigated, using technical equipment or visual observation $[18,19]$. For more advanced investigation of MCI, it is necessary to prove the reliability of tests on the cervical spine.

The aim of the present study was to:

- Assess the inter-rater reliability of active movement control tests of the cervical spine

- Propose a test battery which is easy and efficient to use in practice

\section{Methods}

\section{Study design}

An inter-tester reliability study was performed. Fortyfive participants were videotaped performing a set of thirteen active movement tests on the cervical spine. The test outcomes shown in these recordings were rated as either correct or incorrect by two experienced physiotherapists independently and in random order. The standards for correct and incorrect were defined in advance with the help of two examples. The characterization of tests and correct and incorrect performances are described in Table 1. As displayed in Table 1 if one element was not performed correctly the test was evaluated as incorrect. All videos were rated by the physiotherapists within two days, at home and using their own laptop. Each test could be observed twice. The data were registered by an independent third person and prepared for analysis. Only one rater was blinded to the participants' baseline data. The study was performed in accordance with the Declaration of Helsinki and approval from the local ethics commission (ethical commission of canton Zürich, Switzerland) was received. Written informed consent for participation in the study was obtained from all participants.

\section{Study sample}

Sample size estimation was based on earlier, similar reliability studies [12,20,21]. Forty-five participants were included: 31 patients with idiopathic or traumatic induced neck pain and 14 healthy volunteer subjects. Inclusion criteria for patients were neck pain, but without radiculopathy or neurological signs in the upper extremity and no known structural pathology in the cervical spine. Exclusions criteria were: neck surgery, known vertebrobasilar insufficiency, any recorded malignancy or restricted active movement of the cervical spine. The restricted active movement was examined clinically. Table 2 outlines the parameters for free movement.

The inclusion criteria for healthy subjects were no neck pain and free range of motion of the cervical spine, assessed according to the parameters in Table 2. All participants were required to speak German, in order to complete the Neck Disability Index questionnaire (NDI) [22] and to follow the test instructions.

\section{Test protocol}

Thirteen active tests were chosen to evaluate the movement control of the cervical spine (Figure 1a-1m). 
Table 2 Parameters for free movement

\begin{tabular}{ll}
\hline Movement direction & Parameter \\
\hline Flexion & Minimum $50^{\circ}$ \\
Extension & Minimum $60^{\circ}$ \\
Rotation & Minimum $80^{\circ}$ in each direction \\
Lateral flexion & Minimum $45^{\circ}$ in each direction \\
\hline
\end{tabular}

The test selection was based on descriptions of Sahrmann [9,23], and McDonnell [10,23] and on discussions with experienced colleagues. The selected tests needed to have the capability to be filmed, observed and to contain active movements.
The recordings were made using the Templo motion analysis program (www.contemplas.com) (Figure 2), with standardized camera locations and starting positions of the subject (Table 1). Participants received identical oral instructions. When a participant did not understand how to perform a test the explanation was repeated and, when necessary, demonstrated by the examiner. A definite recording was made of the third performed movement and this was used in the analysis.

\section{Statistical analysis}

The data was analyzed with the statistical programs $R$ and SSPS 19.0 for Windows. The Kappa coefficient, the

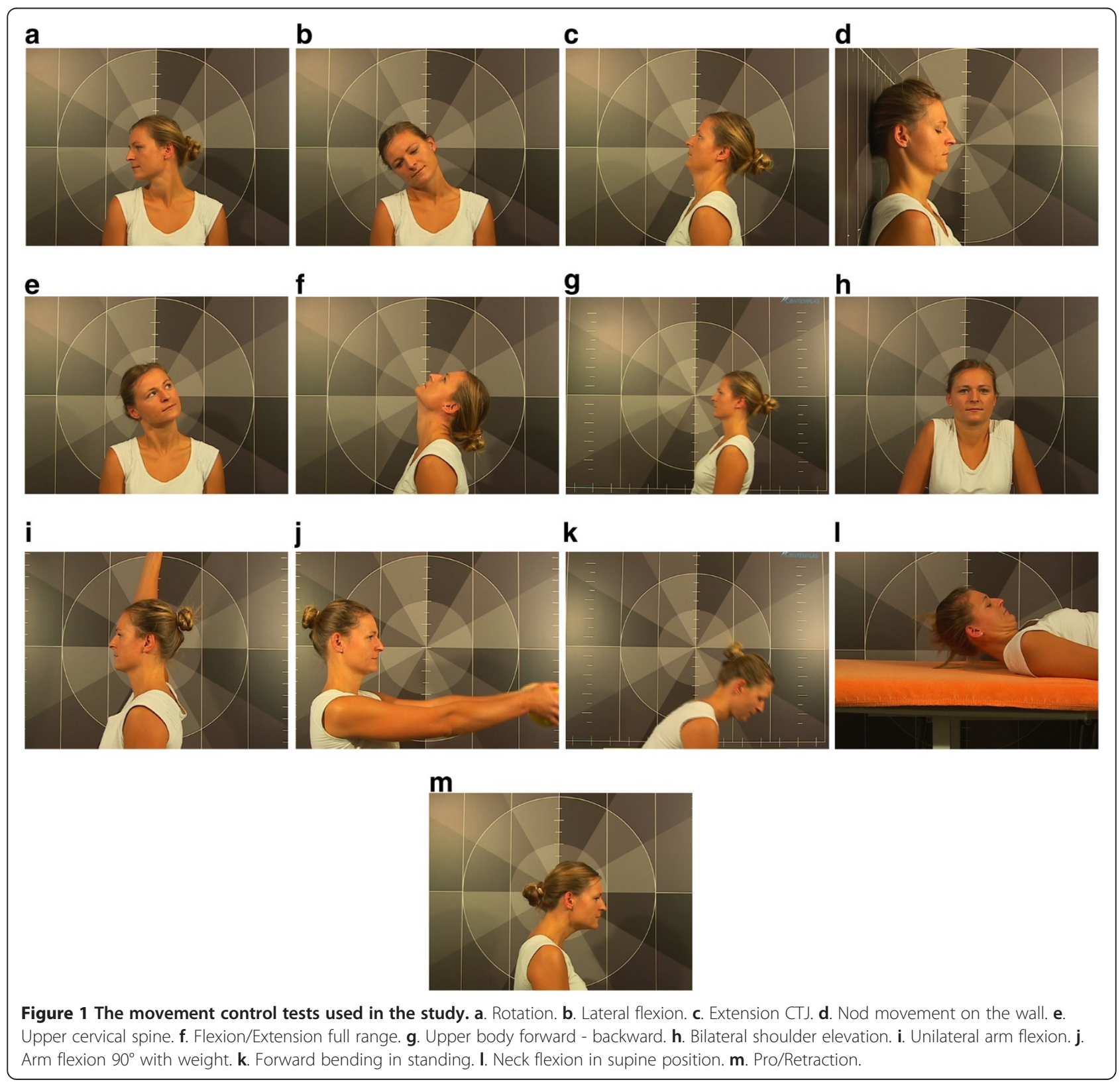




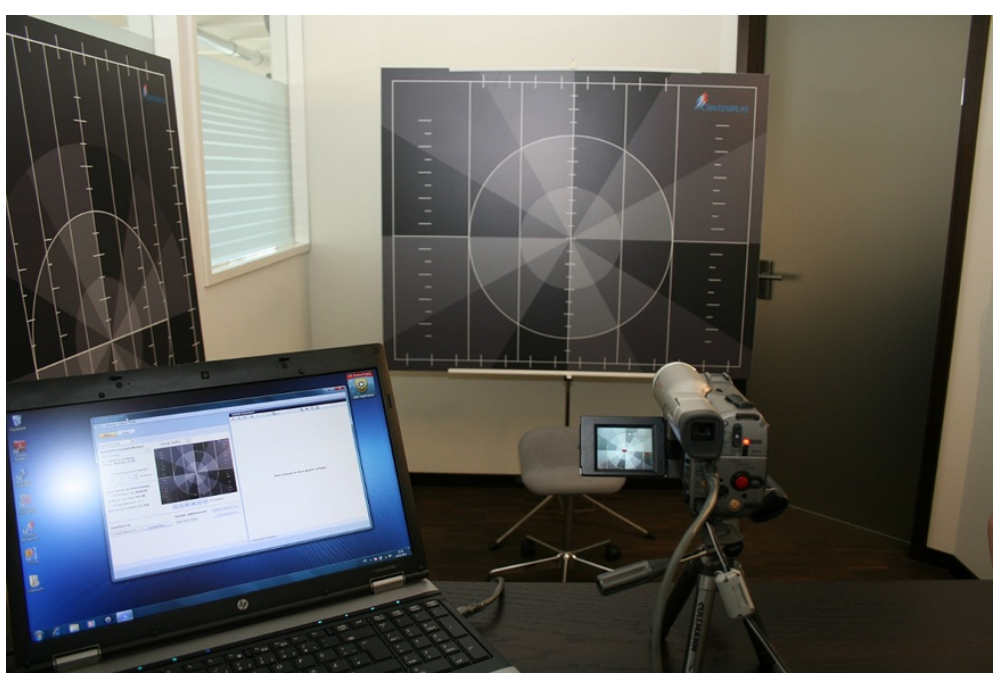

Figure 2 Templo motion analysis program.

95\% CI and the percentage agreement was calculated for each test. A Kappa of 1.0 indicates full agreement with no chance. Kappa values above 0.81 are considered excellent; 0.61 - 0.8 substantial; 0.41-0.6 good; 0.21-0.4 fair; and below 0.2 poor [24]. As in earlier studies [12], the definition of substantial inter-tester reliability was a test result of Kappa above 0.6. Furthermore, the lower bound of the $95 \%$ CI should be higher than 0.4 .

\section{Results}

\section{Subjects}

Baseline data are summarized in Table 3.

\section{Inter-tester reliability}

Table 4 shows an overview of the Kappa, the 95\% CI and the percentage agreement of each movement. The Kappa values were between 0.47-1.0 (Figure 3).

The tests with highest reliability were "bilateral shoulder elevation" and "forward bending in standing" (Kappa of 1). The poorest test was "rotation", which had Kappa below 0.6 and $95 \%$ CI of 0.04-0.89.

Data from the blinded therapist showed that, on average, the patients with neck pain performed 4.6 out of 13 tests incorrectly compared to 2.7 of the healthy subjects.

Table 3 Baseline data

\begin{tabular}{lll}
\hline & Neck pain & Healthy \\
\hline Number & 30 & 15 \\
Female/Male & $26 / 5$ & $7 / 7$ \\
Mean Age (SD) & $38.3(11.2)$ & $39.5(15.9)$ \\
Mean VAS (SD) & $4.3(2.3)$ & \\
Mean NDI Score (SD) & $11.2(6.0)$ & $1.4(2.5)$ \\
Trauma yes/no & $15 / 15$ & $1 / 14$ \\
\hline
\end{tabular}

NDI: Neck Disabilty Index (0-50); SD: Standard Deviation; VAS: Visual analogue scale.
This difference between the groups was highly significant $(\mathrm{p}<0.01)$. Nevertheless, these data were not a subject of follow up in this study.

\section{Discussion}

The aim of the study was to examine the inter-tester reliability of a number of movement control tests for the cervical spine. The results showed good reliability for the performed tasks, although the Kappa values varied largely $(0.23-1.0)$ between the single tests. The tests for "rotatory movements" showed the lowest reliability. One reason for this may be that the tests were taped with only one camera, resulting in a potential loss of the dimensionality of the movement. The threshold of 0.6 can be considered as conservative and strict. A threepoint Likert scale might have resulted in different Kappa values as found in similar studies [25]. However, we decided to use the dichotomy scale (correct/incorrect) in order to keep it simple for the clinical practice. Through the dichotomy scale, it is possible to rate the whole package as a score, where a higher score of positive tests shows a greater movement control deficit.

Only few descriptions of movement control tests for the cervical spine can be found in research literature. Most of the studies analysed a specific muscle group, one specific test or a specific clinical picture [6,7,26-30]. A test battery, consisting of several different tests, has not yet been described. Due to this scarcity of information, and in order to assess and identify the most effective tests, a relatively large number of tests were included. It remains arguable as to whether the tests selected by the authors are the most appropriate for movement control assessment. Further studies need to identify which combination of tests can best differentiate between patients and healthy subjects. 
Table 4 Results of inter-tester reliability

\begin{tabular}{llllllll}
\hline & Rotation & $\begin{array}{l}\text { Lateral } \\
\text { flexion }\end{array}$ & $\begin{array}{l}\text { Extension } \\
\text { CTJ }\end{array}$ & $\begin{array}{l}\text { Nod movement } \\
\text { on the wall }\end{array}$ & $\begin{array}{l}\text { Upper cervical } \\
\text { Rot./LF }\end{array}$ & $\begin{array}{l}\text { Flex./Ext. } \\
\text { full range }\end{array}$ & $\begin{array}{l}\text { Upper body } \\
\text { forward/backward }\end{array}$ \\
\hline Kappa & 0.47 & 0.77 & 0.68 & 0.8 & 0.68 & 0.69 & 0.84 \\
$95 \% \mathrm{Cl}$ & $0.04-0.89$ & $0.55-0.97$ & $0.47-0.9$ & $0.55-1.0$ & $0.47-0.89$ & $0.47-0.9$ & $0.68-0.94$ \\
\% agreement & 93.3 & 88.3 & 84.4 & 95.5 & 84.5 & 84.4 & 94.5 \\
\hline & $\begin{array}{l}\text { Bilateral shoulder } \\
\text { elevation }\end{array}$ & $\begin{array}{l}\text { Unilateral } \\
\text { arm flexion }\end{array}$ & $\begin{array}{l}\text { Arm flexion } \mathbf{9 0}^{\circ} \\
\text { with weight }\end{array}$ & $\begin{array}{l}\text { Forward bending } \\
\text { in standing }\end{array}$ & $\begin{array}{l}\text { Neck flexion in } \\
\text { supine position }\end{array}$ & Pro/retraction \\
\hline Kappa & 1 & 0.74 & 0.85 & 1 & 0.81 & 0.91 \\
$95 \% \mathrm{Cl}$ & & $0.47-0.95$ & $0.55-1.0$ & & $0.61-1.0$ & $0.75-1.0$ \\
\% agreement & 100 & 97.8 & 97.7 & 100 & 93.3 & 96.3 & \\
\hline
\end{tabular}

CTJ:Cervicalthoracic Junction, Rot:: Rotation, LF: Lateralflexion, Flex.: Flexion, Ext.: Extension.

We decided to videotape participants performing the tests to exclude all disruptive elements. This choice also allowed us to rate independently and for at least one of the physiotherapists to remain blinded to the participants. Using the reference lines (Figure 2) we created a laboratory setting. The reference lines helped to videotape in standardized starting positions. For this reason also the Kappa limit was set as high as 0.6. What is not known, however, is whether reliability would be equally as good without these lines. This question remains open and is a limitation of our study.

Different aspects led to the tests chosen in this study. The capability to film and observe was necessary in order to allow easy and efficient handling in practice. Four- point kneeling as an initial position for movement control tests is described by different authors [3,10,23]. But for us, it was difficult to find a standardized film position that would allow an observable evaluation and

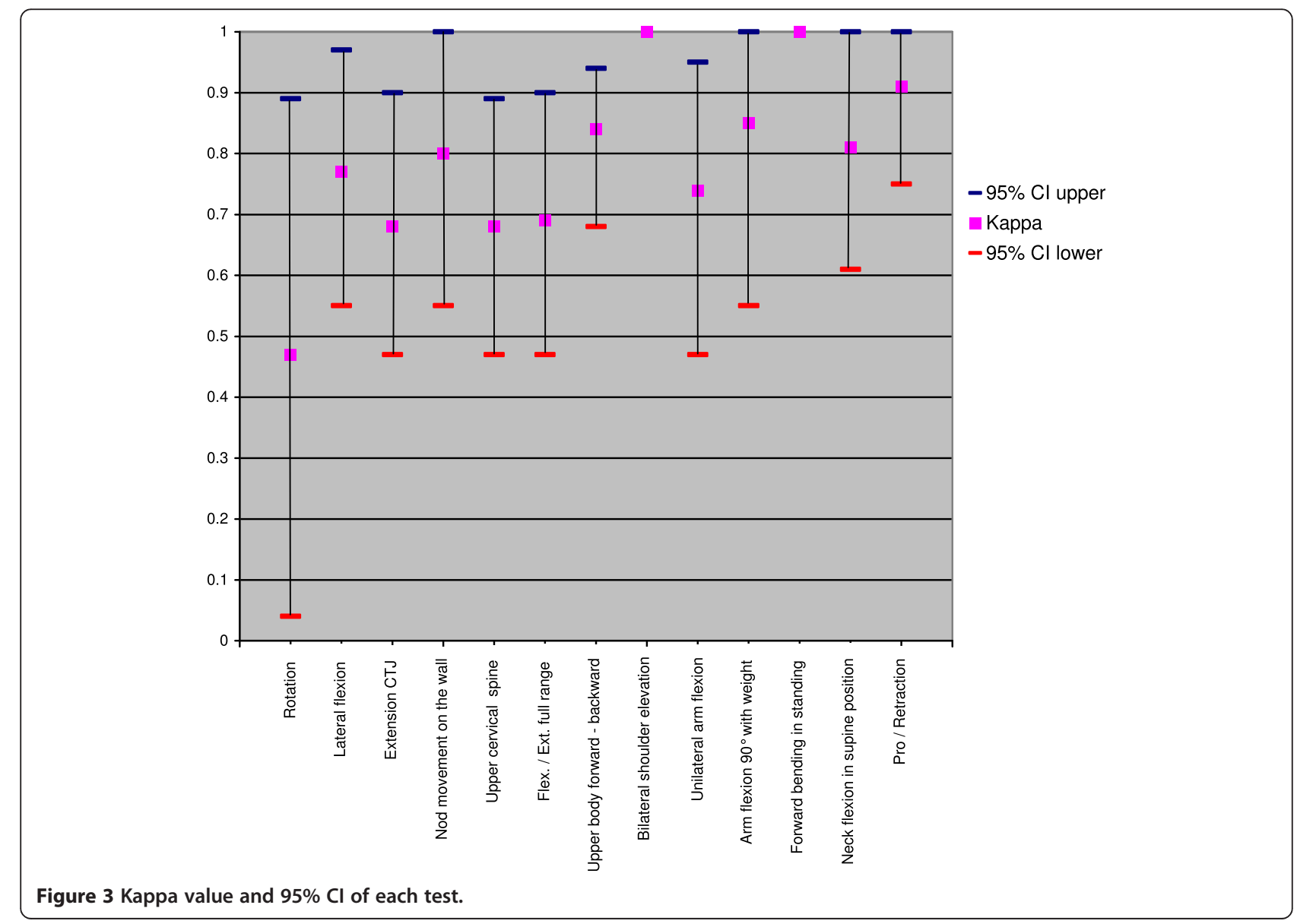


so the decision was made to exclude this position. Additionally, it was important to choose tests which offered an approach to treatment.

Because of the organisation of the study, one of the two raters was not blinded to the subjects' diagnoses. However, this should not have diminished the assessment of reliability.

Patients with specific neck pain (ie. radiculopathy or neurological signs in the upper extremity and structural pathology in the cervical spine) were excluded. Furthermore, the group of patients showing movement impairment (ie restricted active movements), as described by O'Sullivan [4], was also excluded. Pain-free movement was a prerequisite to perform these tests. Not excluded were patients with central maladaptive pain. Participants were not examined for this. There was no differentiation between non-mechanical and mechanical neck pain, which would be important for the clinical relevance of the tests. This can be considered as a further limitation of the study.

As the inclusion criteria indicate, these tests are not relevant to patients showing specific neck pain but for patients with mechanical ischaemic pain through postural and ergonomic causes.

There were more women in the patient group than in the healthy volunteer group. This reflects the epidemiologic data, which provide higher prevalence of neck pain in women than men $[1,31]$. The mean age of the patient group was 38.3 years and was in the age range with peak of prevalence for neck pain [32-34]. Mean VAS (4.3) and NDI (mean 11.2 points/50) showed that patients included in the study did not suffer intense pain and that the pain did not present a significant limitation on their daily lives. This was expected based on the inclusion and exclusion criteria. MCI is not characterized by intense pain and extreme limitation in daily life. Two participants of the healthy subjects group reported historical neck trauma. Since they hadn't experienced a problem for many years, they were included in the healthy subjects group.

Reliable and valid tests are needed which are easy and efficient to use in clinical practice. The authors propose to use the following eight tests as a battery: extension cervicalthoracic junction [CTJ], upper body forward backward, bilateral shoulder elevation, unilateral arm flexion, arm flexion $90^{\circ}$ with weight, forward bending in standing, neck flexion in supine position and pro/retraction. These tests do not require any technical devices and are easy to perform. However, reference lines were used in our study and can be recommended to use in clinical setting also.

Further research should evaluate the intra-tester reliability. Two experienced manual therapists rated the data in the present study. Accordingly, it would be informative to understand how the reliability is affected when rated by less experienced manual therapists.

The significant difference between the performances of patients with neck pain versus healthy subjects shows potential for discriminative power and should be further investigated. It is also recommended to ascertain the appropriate combination of tests for optimal discriminative validity between patients and healthy controls.

\section{Conclusion}

In the present study, patients with neck pain and healthy volunteers were videotaped performing active movement control tests of the cervical spine. The statistical analysis showed good to excellent inter-tester reliability.

Eight tests to be used as a battery are recommended. This test battery can be performed without any technical devices and is fast and efficient in clinical practice.

\section{Abbreviations}

Cl: Confidence interval; CTJ: Cervicalthoracic junction; MCl: Movement control impairment; MI: Movement impairment; NDI: Neck disability index;

VAS: Visual analogue scale.

\section{Competing interests}

The authors declare that they have no competing interests.

\section{Authors' contributions}

$\mathrm{MP}$ and $\mathrm{SH}$ acquired the data, made the videos and were the main authors of the paper. AM did the statistical analysis. HL was involved in the planning, the methodological considerations and revision of the paper. All authors read and approved the final manuscript.

\section{Acknowledgements}

Many thanks go to Christoph Appel, Angelika Hannig and Regula Patroncin for the technical support and the proof-reading of the original manuscript, to Eveline Graf and Karen Linwood for the translation assistance and to all participants in our study. The person in the pictures gave her written consent to allow the publication.

\section{Author details}

'Kantonsspital Winterthur, Brauerstrasse 15, 8401 Winterthur, Switzerland. ${ }^{2}$ Fetzer + Pfund. Physiotherapie. Bewegung. Training, Lindauerstrasse 112, 87439 Kempten, Germany. ${ }^{3}$ Zurich University of Applied Sciences, School of health professions, Institute of Physiotherapy, Technikumstrasse 70, 8400 Winterthur, Switzerland.

Received: 9 July 2014 Accepted: 20 November 2014

Published: 29 November 2014

\section{References}

1. Côté $P$, Cassidy JD, Carroll L: The epidemiology of neck pain: what we have learned from our population-based studies. J Can Ciropr Assoc 2003, 74(4):284-290.

2. Haldeman S, Carroll L, Cassidy JD, Schubert J, Nygren A, Disorders B. a. J. D.-T F. o. N. P. a. I. A: The Bone and Joint Decade 2000-2010 task force on neck pain and its associated disorders: executive summary. Spine (Phila Pa 1976) 2008, 33(4 Suppl):S5-S7. doi:10.1097/BRS.0b013e3181643f40.

3. Jull G, Sterling M, Falla D, Treleaven J, O'Leary S: Whiplash, Headache, and Neck Pain. London: Elsevier Churchill Livingstone; 2008.

4. O'Sullivan P: Diagnosis and classification of chronic low back pain disorders: maladaptive movement and motor control impairments as underlying mechanism. Man Ther 2010, 10(4):242-255. doi:10.1016/j. math.2005.07.001.

5. Luomajoki H: Movement Control Impairment as a Sub-group of Non-specific Low Back Pain. Kuopio: University of Eastern Finland; 2010. 
6. Falla D, Bilenkij G, Jull G: Patients with chronic neck pain demonstrate altered patterns of muscle activation during performance of a functional upper limb task. Spine (Phila Pa 1976) 2004, 29(13):1436-1440. doi:00007632-200407010-00011.

7. Falla D, Jull G, Hodges PW: Feedforward activity of the cervical flexor muscles during voluntary arm movements is delayed in chronic neck pain. Exp Brain Res 2004, 157(1):43-48. doi:10.1007/s00221-003-1814-9.

8. Moseley GL, Hodges PW: Chronic pain and motor control. In Grieve's Modern Manual Therapy, The vertebral column. 3rd edition. Edited by Boyling JD, Jull GA. London: Churchill Livingstone; 2004:215-231.

9. Sahrmann SA: Diagnosis and Treatment of Movement Impairment Syndromes. St.Louis: Mosby; 2002.

10. McDonnell MK: Movement System Syndromes of the Cervical Spine. In Movement System Impairment Syndromes of the Extremities, Cervical and Thoracic Spines. 1st edition. Edited by Sahrmann S. St. Louis: Elsevier Mosby; 2011.

11. Dankaerts W, O'Sullivan PB, Straker LM, Burnett AF, Skouen JS: The inter-examiner reliability of a classification method for non-specific chronic low back pain patients with motor control impairment. Man Ther 2006, 11(1):28-39. doi:10.1016/j.math.2005.02.001.

12. Luomajoki $\mathrm{H}, \mathrm{Kool} J$, de Bruin ED, Airaksinen O: Reliability of movement control tests in the lumbar spine. BMC Musculoskelet Disord 2007, 8:90. doi:10.1186/1471-2474-8-90.

13. Luomajoki $\mathrm{H}, \mathrm{Kool} \mathrm{J}$, de Bruin ED, Airaksinen O: Movement control tests of the low back; evaluation of the difference between patients with low back pain and healthy controls. BMC Musculoskelet Disord 2008, 9:170. doi:10.1186/1471-2474-9-170.

14. Luomajoki $\mathrm{H}, \mathrm{Kool} J$, de Bruin ED, Airaksinen O: Improvement in low back movement control, decreased pain and disability, resulting from specific exercise intervention. Sports Med Arthrosc Rehabil Ther Technol 2010, 2:11. doi:10.1186/1758-2555-2-11.

15. Carlsson H, Rasmussen-Barr E: Clinical screening test for assessing movement control in non-specific low-back pain. a systematic review of intra- and inter-observer reliability studies. Man Ther 2013, 18:103-110.

16. Niere KR, Torney SK: Clinicians' perceptions of minor cervical instability. Man Ther 2004, 9(3):144-150. doi:10.1016/S1356-689X(03)00100-0.

17. O'Leary S, Falla D, Elliott JM, Jull G: Muscle dysfunction in cervical spine pain: implications for assessment and management. J Orthop Sports Phys Ther 2009, 39(5):324-333. doi:10.2519/jospt.2009.2872.

18. Jasiewicz JM, Treleaven J, Condie P, Jull G: Wireless orientation sensors: their suitability to measure head movement for neck pain assessment. Man Ther 2007, 12(4):380-385. doi:10.1016/j.math.2006.07.005.

19. Passier LN, Nasciemento MP, Gesch JM, Haines TP: Physiotherapist observation of head and neck alignment. Physiother Theory Pract 2010, 26(6):416-423. doi:10.3109/09593980903317557.

20. Enoch F, Kjaer P, Elkjaer A, Remvig L, Juul-Kristensen B: Inter-examiner reproducibility of tests for lumbar motor control. BMC Musculoskelet Disord 2011, 12:114.

21. Murphy DR, Byfield D, Mccarthy P, Humphreys K, Gregory AA, Rochon R: Inter-examiner reliability of the hip extension test for suspected inpaired motor control of the lumbar spine. J Manipulative Physiol Ther 2006, 29(5):374-377

22. Vernon $\mathrm{H}$ : The neck disability index: state-of-the-art, 1991-2008. Manipulative Physiol Ther 010, 31(7):491-502. doi:10.1016/j.jmpt.2008.08.006.

23. McDonnell MK, Sahrmann S: Movement - Impairment Syndromes of the Thoracic and Cervical Spine. In Physical Therapy Of The Cervical And Thoracic Spine. 3rd edition. Edited by Grant R. Churchill Livingstone; 2002.

24. Sim J, Wright CC: The kappa statistic in reliability studies: use, interpretation, and sample size requirements. Phys Ther 2005, 85(3):257-268.

25. Della Casa E, Affolter Helbling J, Meichtry A, Luomajoki H, Kool J: Head-Eye movement control tests in patients with chronic neck pain; inter-observer reliability and discriminative validity. BMC Musculoskelet Disord 2014, 15:16

26. Jull G, Kristjansson E, Dall'Alba P: Impairment in the cervical flexors: a comparison of whiplash and insidious onset neck pain patients. Man Ther 2004, 9(2):89-94. doi:10.1016/S1356-689X(03)00086-9.

27. O'Leary S, Jull G, Kim M, Vicenzino B: Cranio-cervical flexor muscle impairment at maximal, moderate, and low loads is a feature of neck pain. Man Ther 2007, 12(1):34-39. doi:10.1016/j.math.2006.02.010.

28. Uthaikhup S, Jull G: Performance in the cranio-cervical flexion test is altered in elderly subjects. Man Ther 2009, 14(5):475-479. doi:10.1016/j. math.2008.12.003.
29. Uthaikhup S, Sterling M, Jull G: Cervical musculoskeletal impairment is common in elders with headache. Man Ther 2009, 14(6):636-641. doi:10.1016/j.math.2008.12.008.

30. Zito G, Jull G, Story I: Clinical tests of musculoskeletal dysfunction in the diagnosis of cervicogenic headache. Man Ther 2006, 11(2):118-129. doi:10.1016/j.math.2005.04.007.

31. Hoy DG, Protani M, De R, Buchbinder R: The epidemiology of neck pain. Best Pract Res Clin Rheumatol 2010, 24(6):783-792. doi:10.1016/j. berh.2011.01.019.

32. Côté P, van der Velde G, Cassidy JD, Carroll LJ, Hogg-Johnson S, Holm LW, Disorders, B. a. J. D.-T. F. o. N. P. a. I: A: the burden and determinants of neck pain in workers: results of the Bone and Joint Decade 2000-2010 task force on neck pain and its associated disorders. Spine (Phila Pa 1976) 2008, 33(4 Suppl):S60-S74. doi:10.1097/BRS.0b013e3181643ee4.

33. Hogg-Johnson S, van der Velde G, Carroll LJ, Holm LW, Cassidy JD, Guzman J, Peloso P: The burden and determinants of neck pain in the general population: results of the Bone and Joint Decade 2000-2010 task force on neck pain and its associated disorders. J Manipulative Physiol Ther 2009, 32(2 Suppl):S46-S60. doi:10.1016/j.jmpt.2008.11.010

34. Manchikanti L, Singh V, Datta S, Cohen SP, Hirsch JA, Physicians AS. o. I. P: Comprehensive review of epidemiology, scope, and impact of spinal pain. Pain Physician 2009, 12(4):E35-E70.

doi:10.1186/1471-2474-15-402

Cite this article as: Patroncini et al:: Reliability of movement control tests on the cervical spine. BMC Musculoskeletal Disorders 2014 15:402.

\section{Submit your next manuscript to BioMed Central and take full advantage of:}

- Convenient online submission

- Thorough peer review

- No space constraints or color figure charges

- Immediate publication on acceptance

- Inclusion in PubMed, CAS, Scopus and Google Scholar

- Research which is freely available for redistribution

Submit your manuscript at www.biomedcentral.com/submit
C Biomed Central 